\title{
THE TASK OF AFRICAN THEOLOGY - PROBLEMS AND SUGGESTIONS
}

John O Akao

University of Ibadan

Nigeria

\begin{abstract}
Though we recognize that theology as a human activity possesses the limitations and particularities of those engaged in it, yet we would like to believe that theology can only become meaningful only if and when it speaks relevantly to a particular community in their historical or spatial and temporal conditions.
\end{abstract}

\section{Introduction}

For the past decades, precisely since the 1960s, scholars in Africa have ceaselessly brainstormed on the issue of evolving an authentic Christian theology that could be called African. The search unhappily coincided with the wave of a new dawn in the continent that witnessed an upsurge of nationalistic frenzy and clamor for independence from erstwhile colonial masters. The circumstances of its emergence to the scene shrouded its aims and purpose with misgivings and misrepresentations. This was more so because a demarcating line could not be drawn between it and the revolutionary spirit of other theologies that erupted in the continent like Black Theology.

Consequently, opponents saw in it a neo-political tendency couched in biblical terms to win sympathy and popular acceptance. The articulation of its subject matter by early scholars easily aligned it with Marxist ideologies and pitched its tent with "black revolution" advocated by black Theology. While many scholars were scared, others sought clarification and delineation like John Mbiti who say: "The concerns of Black Theology differ considerably from those of African theology. Theology differs considerably from those of African theology. The latter grows out of our joy and experience of the Christian faith whereas Black Theology emerges from the pains of oppression ${ }^{1}$. In response Desmund Tutu claims that, "some might feel ashamed that the most serious enterprise in which they have engaged should be characterized as a reaction rather than resulting from their own initiative."

In spite of the differences in perspectives and undaunted by prejudice, African scholars who felt stimulated and challenged by the way Latin American Theologians were articulating their socio-political situation in the light of biblical principles gallantly picked up the gauntlet.

The pathetic theological situation in Africa was calling for concern in that after more than a century of existence on the African soil, the church was still to come to grips with a theology it could proudly call its own. While the Latin Americans were fine-tuning their Liberation theology and the Asians romanticizing their fledging theologies, the Africans had nothing, even a heresy, to show to the world.

The first task that confronted African scholars in this new venture was how to emasculate the theological process in vogue from its western educational philosophies and trappings so as

1. John Mbiti, "An African views American Black Theology" in Black Theology: A documentary History, 19661979, ed., Gayraud, S, Wilmore and James, Cone, H. Orbis Books, Maryknoll, NY, 1979, pp. 478-81.

2. Desmond Tutu, "Black Theology/African Theology - Soul Mates or Antagonists?" in Third World Liberation Theologies: A Reader, ed., Deane William, Ferm, Orbis Books, Maryknoll, NY, 1986, p. 260. 
to recloth it in an African garb. The fact that the scholars who set to do this were themselves trained with a mind set well steeped in western educational thought mould bedeviled the initial efforts. Added to this was the desire to maintain unflinching the inherited age-long Christian orthodoxy as it was handed over by the missionaries. Caught in the ugly web, much talk was emitted with little or no concrete results.

\section{Problems of the enterprise}

The christening of the theological project has been as difficult as defining its borders and mapping out its content. The search for an appropriate nomenclature had led to a number of Suggestions, like, African Christian. Theology, Christian African Theology, African Theology, Black Theology, Liberation Theology, Enculturation Theology, Incarnation Theology, Indigenization Theology, Situation Theology etc. ${ }^{3}$ Though each of the titles has something peculiar in its meaning content which differentiates it from the others there is scarcely any one that is not prone to ambivalent interpretation. This may account for the lack of unanimity on the label for the theological enterprise. While the debate on nomenclature continues, some scholars have ventured into highlighting the available resources which the project could tap to enrich itself. This has been found to be richly and readily available in the field of our autochthonous religious heritage.

Extrapolations from our traditional heritage has given birth to some Christocentric and anthropocentric models for doing African Theology which have raised some dust among scholars. Prominent among suggestions made are: taking Jesus for our ancestor; ${ }^{4}$ master of initiation $;{ }^{5}$ healer; ${ }^{6}$ divine chameleon; ${ }^{7}$ African king $;{ }^{8}$ black Messiah $;{ }^{9}$ elder brother; etc. Much as the titles or some of them may help the reflection of the African as he struggles to relate the bible to his community and existential circumstances, the fact remains that Jesus can not be seen to actually fit the picture painted of him. This makes the enterprise too philosophical to adequately address the stark reality of the theological needs of the African. The preferred analogies or can anthropocentric models cannot meaningfully address the dual nature of Jesus, human and divine.

Though we recognize that theology as a human activity possesses the limitations and particularities of those engaged in it, yet we would like to believe that theology can only become meaningful only if and when it speaks relevantly to a particular community in their historical or spatial and temporal conditions. We do not, by any means, imply that any theology can be perfect, rather, it is assumed that inadequate models or improper methods of theologization can greatly hamper the enterprise and put at risk the fruits otherwise attainable

3. See John Mbiti, "The Biblical Basis for Present Trends in African Theology" in African Theology en route, ed., Kofi Appiah-Kubi and Sergio Torres, Orbis Books, Maryknoll, NY, 1979, p. 83. A Shorter African Christian Theology, Geoffrey Chapman, 1975, p. 27ff; Mosala, IJ and Tlhagale, BEd., Black Theology from South Africa: The Unquestionable Right to be Free, Orbis Books, Maryknoll, NY, 1986; Waliggo, JM et. al. Inculturation: Its Meaning and Urgency, Nairobi. St. Paul Publications Africa, 1986. Frostin, P Liberation Theology in Tanzania and South Africa: A First World Interpretation, Lund: Lund University Press, 1988, etc.

4. Charles Nyamiti, Christ,Our Ancestor: Christology from an African Perspective, Gwero, Zimbabwe: Mambo Press, 1984, also John S Pobee, Toward an African Theology, Nashville:Abingdon, 1978, pp. 17-18.

5. Raymond, Moloney, "African Christology", in Theological Studies, Vol. 48 (1987), pp. 505ff.

6. Aylward Shorter, Jesus and the Witch doctor: An Approach to Healing and Wholeness, London: Chapman, Orbis Books, 1985.

7. John Mbiti, Akamba Stories, Oxford: Clavendon Press, 1966, pp. 14ff.

8. Chris Manus, Jesu Kristi Oba: A Christology of "Christ the King". Among the Indigenous Christian Churches in Yorubaland Nigreria, in Asia Journal of Theology, Vol. 5, (1991), pp. $311 \mathrm{ff}$.

9. Ernilio de Carvalho, JM. "What do the Africans say that Jesus Christ is?" in Africa Theological Journal Vol 10, (1981), no. 2, pp. 17-25. 
from the exercise. The channels or models through which the dynamic word of God, unsheathed by the theologians, routed to the faithful in form of their perception and understanding of divine human cosmic relationship, God's intervention in human affairs, may vary from one situation to the other but the communication channel must not distort the intervention. The theological models to be employed in African Theology are therefore as important as the organizing factors that constitute the hermeneutical enterprise.

\section{Hermeneutical pivot}

In suggesting a hermeneutical pivot for African theology, one should bear in mind the requirement that makes it imperative for such pivot to qualify as a theological constant. When situations change the mode of theologization changes, as the people adjust to new circumstances of life. In African theology, the organizing factor should be as constant as Jesus and the Cross are to New Testament Theology irrespective of the context in which the theologization is done. Though human situations may change but the organizing factor "Hope" in African Theology will remain relevant and in constant dialogue with the past, present and future. The past provides it with a base and referents and the present supplies the rationale not to despair in spite of all the odds while the future informs the mind on ultimate divine vindication and reward in the terrestrial struggle or celestial judgment.

As a hermeneutical principle, "hope" is relevant for both black and white Africans, oppressors and the oppressed although the difference will be found to inhere in the situations where it is applied. This gives a global hue to the content of African Theology instead of making it a contra-productive preserve of oppressed Africans. For the Africans passing through varying and different socio-historical and economic phases "hope" will be found an adequate catalyst for hermeneutical nuances. As God and history are not static, but inexorably working for a purpose, hope underscores God's requirement to enable man walk with him irrespective of his situation in life for the achievement of His purpose for him. In the search for freedom, power, self-identity and actualization, hope is a major ingredient for mobilization and implementation. It boosts morale and entrenches the determinative will to succeed.

\section{Conclusion}

We are conscious of the possibility of subsuming hope under cowardice or docility by ardent advocates of revolution and violence. But the fact remains that while "hope" is biblical, the alternative is not. The events in Nigeria under the dictatorial regime of General Sani Abacha, when the people's hope for divine intervention vindicated them, are a living testimony. A theology based on such a parameter will stand the test of time. 